Jurnal Indonesia Sosial Teknologi: p-ISSN: 2723 - 6609

e-ISSN : 2745-5254

Vol. 2, No. 5 Mei 2021

\title{
PENGARUH PERKULIAHAN DARING TERHADAP EFEKTIVITAS PEMBELAJARAN MAHASISWA PROGRAM STUDI ADMINISTRASI PUBLIK UNIVERSITAS PEMBANGUNAN NASIONAL "VETERAN" JAWA TIMUR DI ERA PANDEMI COVID 19
}

\author{
Ananta Pratama, Novia Cahyaningrum, Ayu Wulandari dan Siska Zunita \\ Anggraini \\ Program Studi Administrasi Publik, UPN "Veteran" Jawa Timur. \\ Email: prathama.ananta@gmail.com, 5114211.wulan@gmail.com, \\ novia.chyngrm@gmail.com, siskazun15@gmail.com.
}

\begin{abstract}
Online lectures are government policies that are the main means of learning during the COVID-19 pandemic. This is also applied at the Veteran National Development University of East Java, which follows the government's recommendation to carry out online activities using online application facilities, such as whatsapp groups, zoom, google classroom, and other application media. This research aims to analyze the effectiveness of online lectures for Administration Study Program students. Public of the Faculty of Social and Political Sciences during the COVID19 Pandemic. This research is a quantitative descriptive study using an online survey method via google form. The results of the test showed that the majority of students from the Public Administration Study Program, Faculty of Social and Political Sciences, Veteran National Development University, East Java, attended online lectures at home using gadgets through a zoom application that was accessed using wifi and the data connection was in a fairly good signal condition. Online lectures provide a general picture that online lectures are less than optimal in understanding the material provided to students, resulting in an ineffective lecture process. Other results show that students are ready to face the new rules of the new normal live when lectures are held offline. As for the lecture system that is effective during a pandemic, it is alternating online and offline by paying attention to the principles of the COVID-19 prevention protocol.
\end{abstract}

Keyword: effectiveness; online lecture; COVID-19.

\begin{abstract}
Abstrak
Perkuliahan daring (online) merupakan kebijakan pemerintah yang menjadi sarana utama dalam pembelajaran ketika wabah Pandemi COVID-19. Hal ini juga diterapkan di Universitas Pembangunan Nasional Veteran Jawa Timur yang mengikuti anjuran pemerintah untuk melakukan kegiatan daring yang menggunakan sarana aplikasi online, seperti whatsapp grup, zoom, google classroom, dan media aplikasi lain. Penelitian ini bertujuan untuk menganalisis efektifitas perkuliahan daring pada mahasiswa Prodi Administrasi Publik Fakultas Ilmu Sosial dan Politik di saat Pandemi COVID-19. Penelitian ini merupakan penelitian deskriptif kuantitatif dengan menggunakan metode survey melalui
\end{abstract}


google form secara online. Hasil pengujiannya dihasilkan bahwa mayoritas mahasiswa Prodi Administrasi Publik Fakultas Ilmu Sosial Dan Ilmu Politik Universitas Pembangunan Nasional Veteran Jawa Timur mengikuti perkuliahan daring dirumah menggunakan gadget $(\mathrm{Hp})$ melalui aplikasi zoom yang di akses menggunakan wifi dan koneksi data dalam keadaan sinyal yang cukup baik. Perkuliahan daring memberikan gambaran secara umum bahwa perkuliahan daring ini kurang optimalnya pemahaman materi yang di berikan pada mahasiswa sehingga mengakibatkan proses perkuliahan yang kurang efektif. Hasil lain menunjukkan bahwa mahasiswa siap menghadapi aturan baru the new normal live apabila dilaksanakan perkuliahan secara luring. Sedangkan untuk sistem perkuliahan yang efektif selama pandemi adalah daring dan luring secara bergantian dengan memperhatikan prinsip protocol pencegahan COVID-19.

Kata kunci: efektifitas; perkuliahan daring COVID-19.

\section{Pendahuluan}

Kehidupan dunia pada akhir 2019 awal Tahun 2020 dihebohkan dengan munculnya suatu penyakit menular dan mematikan yang bermula ditemukan di daerah Wuhan, China. Penyakit menular ini disebabkan oleh sindrom pernapasan akut oleh corona virus 2 (severe acute respiratory syndrome coronavirus 2 atau SARS-CoV-2). Virus itu kemudian diberi nama COVID-19 atau dengan nama lengkap Coronavirus disease-2019 yang disingkat menjadi COVID-19 Virus tersebut merupakan keluarga besar dari corona virus yang dapat menyerang hewan. Penyakit ini awalnya menurut informasi dari Negara China merupakan penyakit yang berasal dari hewan yang menular ke manusia yang berada di Pasar hewan Wuhan, China, Corona menyebabkan penyakit infeksi saluran pernafasan, seperti flu, MERS (Middle East Respiratory Syndrome), dan SARS (Severe Acute Respiratory Syndrome). Sejak ditemukan virus ini telah menyebar secara luas hingga mengakibatkan pandemi global yang berlangsung hingga saat ini. Gejala COVID-19 umumnya berupa demam $38^{\circ} \mathrm{C}$, batuk kering, dan sesak nafas serta dampak paling buruk untuk manusia ialah kematian. Sampai hari ini jumlah pasien terinfeksi masih terus bertambah di seluruh dunia dan belum ditemukan vaksin untuk mencegah berkembangnya virus ini (Widiyono, 2020).

Pandemi global ini juga merebak di hampir seluruh wilayah Indonesia pada tanggal 2 maret 2020. Hal ini membuat pemerintah Indonesia mengeluarkan beberapa inisiatif dalam merespons pandemi COVID-19 dan semua pihak yang terkait berupaya ikut berperan serta dalam mengatasinya. Pemerintah memberikan himbauan kepada masyarakat agar menjaga kebersihan diri dan lingkungan sekaligus tak banyak melakukan aktivitas di luar rumah. Oleh karena itu pemerintah akhirnya memutuskan kebijakan untuk masyarakat beraktivitas dari rumah agar menghindari diri dari kerumunan. Dengan cara ini diharapkan dapat menghindari terjangkit virus dan memutus mata rantai penyebaran virus tersebut. Keputusan pemerintah untuk memberlakukan pembatasan sosial berskala besar (PSBB) merupakan kebijakan yang dipilih dalam merespon adanya Kedaruratan Kesehatan. Undang-Undang Nomor 6 
tahun 2018 menjadi dasar hukum adanya kebijakan tersebut. Dampak pandemi ini pengaruhnya sangat besar terhadap kehidupan. Salah satu dampak pandemi ini adalah pengaruh yang cukup besar terhadap aktivitas di bidang pendidikan. Ini tentu tidak hanya terjadi di Indonesia melainkan juga di seluruh dunia. Beberapa akibat dari pandemi COVID-19 terhadap dunia pendidikan yang dapat disebutkan antara lain adalah penutupan sekolah-sekolah, mulai dari pendidikan usia dini, sekolah dasar dan menengah hingga universitas. Pemerintah Indonesia melalui Kementerian Pendidikan dan Kebudayaan dan Kementerian Agama RI, mengeluarkan kebijakan dengan menerapkan kebijakan belajar dan bekerja dari rumah (Work from Home) mulai pertengahan Maret 2020 dengan sistem pembelajaran jarak jauh dan membuka platform pendidikan daring yang dapat digunakan sekolah dan guru untuk menjangkau peserta didik dari jarak jauh dan membatasi hambatan di dalam menjalankan pendidikan. Sehubungan dengan perkembangan tersebut, Kementerian Pendidikan dan Kebudayaan (Kemendikbud) turut mengambil kebijakan sebagai panduan dalam menghadapi penyakit tersebut di tingkat satuan pendidikan (Kemendikbud, 2020).

Efektivitas sesungguhnya merupakan suatu konsep yang luas, mencakup berbagai faktor didalam maupun diluar organisasi. Efektivitas secara umum menunjukan seberapa jauh tercapainya suatu tujuan yang terlebih dahulu ditentukan. Mengatakan bahwa "efektifitas berasal dari kata "efek" dan digunakan istilah ini sebagai hubungan sebab akibat. "Efektivitas dapat dipandang sebagai suatu sebab akibat dari variabel lain. Efektivitas merupakan salah satu dimensi dari produktivitas, yaitu mengarah kepada pencapaian untuk kerja yang maksimal, yaitu pencapaian target yang berkaitan dengan kualitas, kuantitas dan waktu (Widiyarta \& Jayusman, 2017).

Menurut (Muchtar \& Muntafa, 2015), pada dasarnya pengertian efektivitas yang umum menunjukkan pada taraf tercapainya hasil. Dengan kata lain efektivitas menekankan pada hasil yang dicapai. Sedangkan menurut Supardi, efektivitas adalah ukuran yang menyatakan sejauh mana sasaran/tujuan (kuantitas, kualitas, dan waktu) telah dicapai (Alhogbi, 2017).

Istilah daring merupakan akronim dari "dalam jaringan "yaitu suatu kegiatan yang dilaksanakan dengan sistem daring yang memanfaatkan internet. "Pembelajaran daring merupakan program penyelenggaraan kelas pembelajaran dalam jaringan untuk menjangkau kelompok target yang masif dan luas". "Pembelajaran daring adalah pembelajaran yang menggunakan teknologi multimedia, kelas virtual, CD ROM, streaming video, pesan suara, email dan telepon konferensi, teks online animasi, dan video streaming online". Sementara itu Rosenberg dalam Alimuddin, menekankan bahwa e-learning merujuk pada penggunaan teknologi internet untuk mengirimkan serangkaian solusi yang dapat meningkatkan pengetahuan dan keterampilan.

Daring memberikan metode pembelajaran yang efektif, seperti berlatih dengan adanya umpan balik terkait, menggabungkan kolaborasi kegiatan dengan belajar mandiri, personalisasi pembelajaran berdasarkan kebutuhan mahasiswa dan menggunakan simulasi dan permainan”. Sementara itu menurut Permendikbud No. 
109/2013 pendidikan jarak jauh adalah proses belajar mengajar yang dilakukan secara jarak jauh melalui penggunaan berbagai media komunikasi.

Dari pengertian di atas, dapat disimpulkan bahwa pembelajaran daring atau elearning merupakan suatu pembelajaran yang memanfaatkan teknologi dengan menggunakan internet dimana dalam proses pembelajarannya tidak dilakukan dengan face to face tetapi menggunakan media elektronik yang mampu memudahkan siswa untuk belajar kapanpun dan dimanapun (Kamayanthy, 2020).

Pandemi adalah wabah penyakit yang menjangkit secara serempak dimanamana, meliputi daerah geografis yang luas. Pandemi merupakan epidemi yang menyebar hampir ke seluruh negara atau pun benua dan biasanya mengenai banyak orang. Peningkatan angka penyakit diatas normal yang biasanya terjadi, penyakit ini pun terjadi secara tiba-tiba pada populasi suatu area geografis tertentu. (A.M. Мамонтов, n.d.)

Coronavirus Disease (COVID-19) adalah penyakit menular yang disebabkan oleh virus corona yang baru ditemukan dan dikenal sebagai sindrom pernafasan akut atau parah virus corona 2 (SARS-CoV-2). Coronavirus Disease ialah jenis penyakit yang belum teridentifikasi sebelumnya oleh manusia, virus ini dapat menular dari manusia ke manusia melalui kontak erat yang sering terjadi, orang yang memiliki resiko tinggi tertular penyakit ini ialah orang yang melakukan kontak erat dengan pesien COVID-19 yakni dokter dan perawat (Archika, 2020).

World Health Organization (WHO) menetapkan tentang virus corona atau yang biasa disebut dengan COVID 19 yang menjadi pandemi karena virus ini telah menyebar ke berbagai negara bahkan sudah mendunia. WHO mengartikan pandemi sebagai suatu kondisi populasi pada dunia dan berpotensi menjadikan jatuh dan sakit. Pandemi sendiri adalah wabah yang berjangkit secara bersamaan dmana-mana yang menyebar luas. Pandemi COVID 19 ini juga berdampak dari berbagai sektor kehidupan seperti ekonomi, sosial dan juga pendidikan. Organisasi Pendidikan, Keilmuan, dan Kebudayaan Perserikatan Bangsa-Bangsa atau United Educational, Scientific, and Cultural Organization (UNESCO) pada hari kamis 5 maret 2020 menyatakan bahwa wabah COVID 19 ini telah berdampak pada dunia pendidikan (Irawan, 2020).

Hampir 300 juta siswa terganggu kegiatan sekolahnya di seluruh dunia dan terancam berdampak pada hak-hak pendidikan mereka di masa depan. Di Indonesia sendiri, dunia pendidikan juga ikut merasakan dampaknya. Jika kondisi seperti ini terus meningkat, maka sudah bisa dipastikan dampaknya terhadap sektor pendidikan juga akan semakin meningkat. Dampak yang paling dirasakan adalah peserta didik di instansi penyelenggara pelayanan pendidikan, seperti sekolah disemua tingkatan, lembaga pendidikan non formal hingga perguruan tinggi beradaptasi untuk belajar secara tidak langsung dalam artian secara daring.

Berbagai bentuk kajian yang sudah membahas mengenai pembelajaran daring selama Covid-19 pernah dilakukan oleh beberapa Peneliti. Berdasarkan data terbaru, ditemukan hasil penelitian dari: (1) (Darmalaksana et al., 2020) yang menujukan efektifitas pembelajaran daring dengan capaian yang signifikan seiring dengan tuntutan 
mewujudkan pemimpin digital pendidikan tinggi abad 21; (2) (Sanjaya, 2020) mengkaji tentang 21 refleksi pembelajaran daring di masa darurat Covid-19; (3) Pembelajaran secara daring telah menjadi tuntutan dunia pendidikan sejak beberapa tahun terakhir (He et al., 2014); (4) Melalui pembelajarn daring akan tercipta sebuah pendidikan tinggi dengan lingkungan belajar modern (Huda et al., 2018); (5) (Hikmat et al., 2020) tentang efektivitas pembalajaran daring selama masa pandemi Covid-19; dan (6) (Maulana \& Hamidi, 2020) yang menjelaskan bahwa pada perkuliahan daring mahasiswa memerlukan variasi tersendiri dan mereka lebih menyukai pembelajaran daring sebagai variasi cara mengembangkan dan penyampaian materi.

Berdasarkan hasil penelitian tersebut, peneliti ingin memberikan sebuah gambaran umum terkait pengaruh pelaksanaan daring terhadap pengaruh efektivitas pembelajaran pada mahasiswa Program Studi Administrasi Publik UPN "Veteran" Jawa Timur di saat Pandemi COVID-19 dengan melakukan survey kepada mahasiswa, dengan mengikuti kajian dan hasil penelitian yang sudah ada. Dengan adanya penelitian ini diharapkan dapat memberikan informasi terhadap hasil proses perkuliahan daring supaya memberikan dampak positif terhadap keefektifan proses perkuliahan selama pandemi serta mendukung pengambilan keputusan berkaitan dengan kebijakan di bidang pendidikan pasca pandemi COVID-19. Beberapa hal dapat dilakukan antara lain melihat dan mengantipasi situasi ke depan agar dapat mempersiapkan diri memperbaiki sistem pembelajaran yang lebih maju dan modern.

\section{Metode Penelitian}

Penelitian ini merupakan penelitian deskriptif kuantitatif dengan menggunakan metode survey yang dilakukan secara online (Sugiyono, 2017). Pengumpulan data primer dalam penelitian ini dilakukan dengan menyebarkan kuesioner secara online responden yang merupakan mahasiswa Prodi Administrasi Publik UPN "Veteran" Jatim yang terdiri dari 3 angkatan yang merupakan mahasiswa semester 2,4 dan semester 6 . Dengan jumlah 114 sampel menggunakan metode kuesioner.

Data diperoleh melalui pengisian pertanyaan-pertanyaan yang dibagikan kepada seluruh responden dalam bentuk google form. Selanjutnya data yang terkumpul di analisis untuk dideskripsikan. Komponen yang terdapat dalam kuesioner terdiri atas beberapa pertanyaan yaitu (1) Dimanakah Lokasi anda biasanya mengikuti perkuliahan daring selama wabah pandemi COVID-19; (2) Jenis koneksi internet apa yang sering anda pergunakan selama perkuliahan daring; (3) Aplikasi apa yang anda gunakan pada saat pelaksanaan perkuliahan daring (online); (4) Apakah selama perkuliahan daring (online) anda memahami pembelajaran perkuliahan; (5) Jenis perkuliahan yang seperti apa yang anda harapkan selama pandemi COVID-19; \&(6) Kendala apa yang anda hadapi pada saat pelaksanaan perkuliahan (7) Pengaruh nilai pada saat perkuliahan daring (online).(8) Apakah anda sudah siap terhadap aturan baru terhadap the new normal live (tatanan hidup baru) selama perkuliahan luring. 


\section{Hasil dan Pembahasan \\ Profil Singkat Responden}

Responden dalam penelitian ini adalah mahasiswa Program Studi Administrasi Publik, UPN "Veteran" Jawa Timur dengan responden mahasiswa semester 2,4 dan 6. Responden yang bersedia mengisi kuesioner di google form sejumlah 114 mahasiswa. Untuk sebaran jumlah responden adalah sebagai berikut:

\section{SEMESTER}

114 jawaban

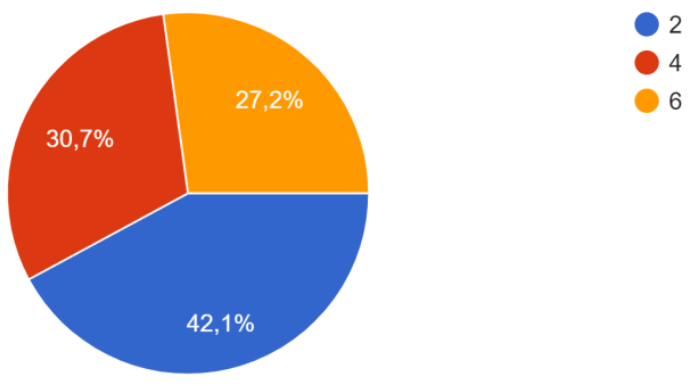

\section{Gambar 1. Sebaran responden yang mengisi kuesioner}

Penelitian Berdasarkan gambar tersebut diketahui bahwa jumlah partisipasi mahasiswa aktif dalam pengisian kuesioner dengan memberikan tanggapan adalah mahasiswa semester 2 sebanyak $42,1 \%$.

\section{Kondisi Perkuliahan Daring}

Pelaksanaan perkuliahan daring memerlukan evaluasi persiapan perguruan tinggi dan juga memerlukan evaluasi dari dosen dan para mahasiswa (Rusdiana \& Nugroho, 2020). Kondisi perkuliahan daring yang dibahas terdiri dari lokasi yang sering digunakan selama perkuliahan daring, jenis koneksi internet selama perkuliahan daring, platform (aplikasi) yang digunakan pada saat pelaksanaan daring, pemahaman pembelajaran daring selama pandemi COVID-19, jenis sistem perkuliahan yang diharapkan mahasiswa selama pandemi COVID-19, kendala yang dihadapi pada saat pelaksanaan pembelajaran daring, pengaruh nilai pada saat perkuliahan daring, dan kesiapan terhadap aturan baru terhadap the new normal live (tatanan hidup baru) selama perkuliahan luring. Untuk data lengkapnya dapat dilihat pada gambar di bawah ini. 
Dimanakah tempat/lokasi yang sering Anda gunakan selama melaksanakan perkuliahan daring ? 114 jawaban
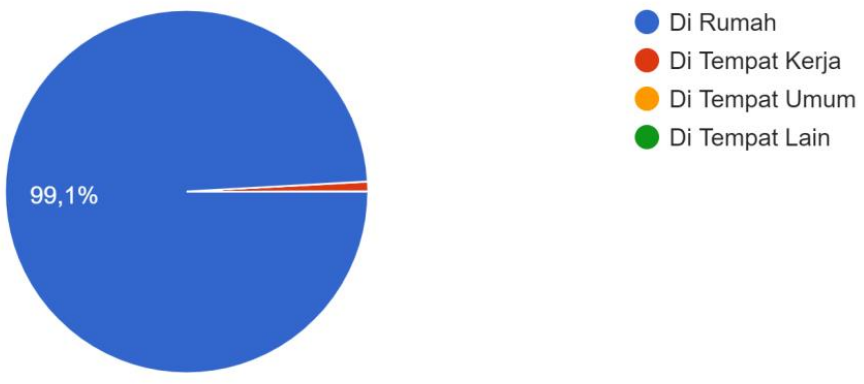

\section{Gambar 2. Lokasi selama perkuliahan daring}

Saat Pandemi COVID-19 Perkuliahan daring mahasiswa Prodi Administrasi Publik disaat Pandemi COVID-19 dilakukan dirumah sejumlah 99,01\%. Sedangkan yang paling sedikit dilakukan ditempat kerja sejumlah 09\%. Pada kondisi ini, mahasiswa Prodi Administrasi Publik menunjukkan kepatuhan terhadap aturan pemerintah untuk lebih banyak melakukan aktivitas belajar dirumah (stay at home) sebagai bentuk upaya pencegahan terhadap wabah COVID-19.

Jenis koneksi internet apa yang Anda gunakan selama perkuliahan daring?

114 jawaban

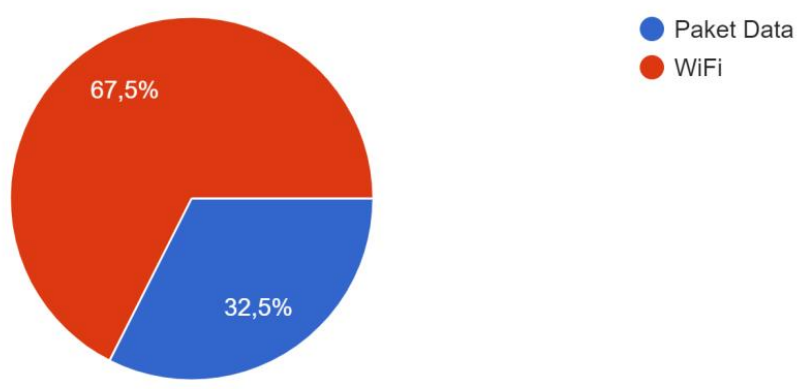

Gambar 3. Jenis koneksi internet selama perkuliahan daring

Pada kondisi koneksi internet, mahasiswa Prodi Administrasi Publik lebih memilih untuk menggunakan wifi sejumlah $67,05 \%$ dibanding dengan menggunakan paket data internet dengan persentase $32,05 \%$. Hasil ini memberikan sebuah gambaran bahwa koneksi wifi lebih fleksibel dibanding dengan menggunakan paket data dirumah karena memerlukan tambahan biaya pengeluaran. Penggunaan jaringan wifi dapat lebih fleksibel, sinyal kuat dan lancar membuat mahasiswa selalu terhubung internet kapan pun tidak mengalami kendala jika jaringan putus karena sinyal data dan kehabisan paket 
data. Sedangakan untuk paket data mahasiswa harus membutuhkan jaringan sinyal yang kuat dan stabil terlebih dahulu dengan kuota paket data penuh.

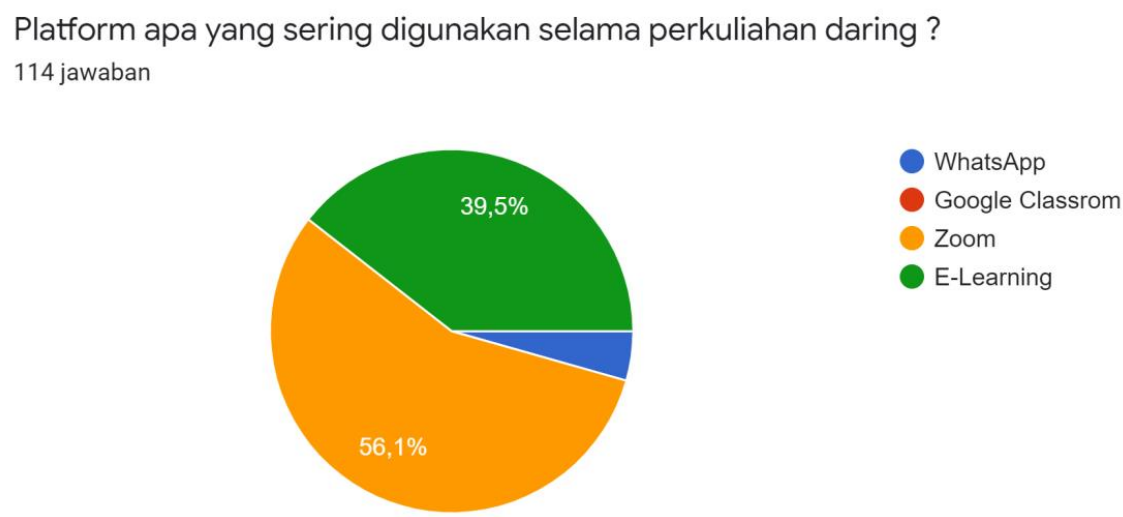

\section{Gambar 4. Platfrom yang sering dipergunakan selama perkuliahan daring}

Perkuliahan daring pada mahasiswa Prodi Administrasi Publik menggunakan beberapa aplikasi pembelajaran secara umum, seperti whatsapp grup, google classroom, dan aplikasi lain (e-learning dan zoom). Pada kondisi ini terlihat bahwa 56,01\% mahasiswa lebih memilih belajar dengan sistem perkuliahan daring menggunakan aplikasi zoom, sedangkan urutan ke 2 yang dipilih mahasiswa dalam perkuliahan daring adalah e-learning yaitu sejumlah 39,05\% selanjutnya untuk urutan ketiga adalah aplikasi whatsaapp sejumlah 4,94\%. Mahasiswa memilih aplikasi zoom karena keunggulan yang digunakan 1) Mahasiswa bisa secara langsung tatap muka dengan dosen, 2) Mempermudah untuk diskusi serta tanya jawab, 3) Akses kapasitas ruang diberikan oleh teknologi ini cukup besar, 4) Mendukung semua platform dan Sebagai media bahan presentasi.

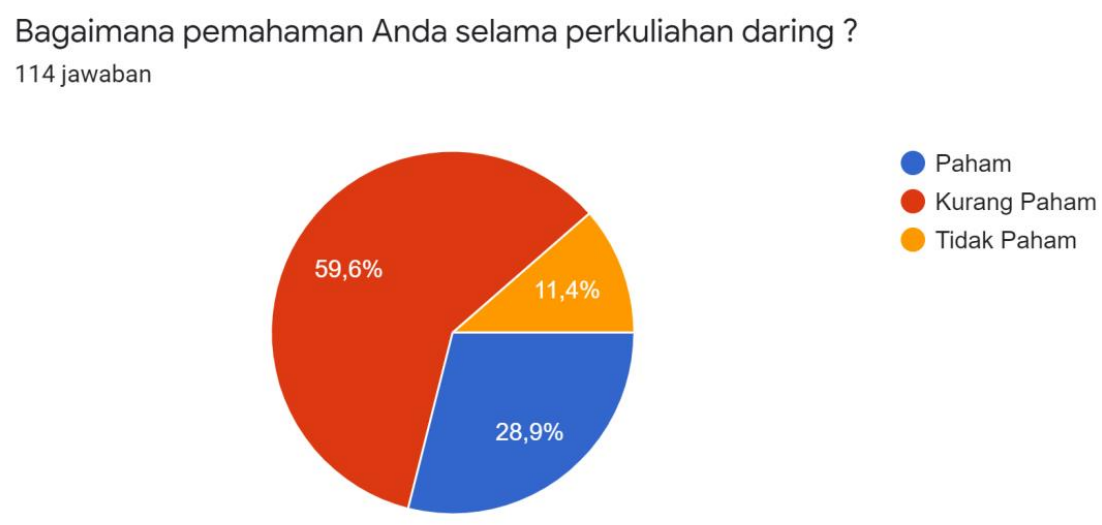

Gambar 5. Pemahaman pembelajaran daring selama Pandemi COVID 19

Berdasarkan gambar tersebut ditemukan bahwa pemahaman perkuliahan daring pada saat pandemi COVID-19 terlihat bahwa mahasiswa yang kurang paham terhadap 
materi sangat besar yaitu 59,06\%, untuk mahasiswa yang paham terhadap materi sejumlah $28,09 \%$, dan mahasiswa yang tidak paham terhadap materi sejumlah $11,04 \%$. Dengan hasil tersebut, dapat kita simpulkan bahwa proses perkuliahan daring selama wabah COVID-19 kurang efektif karena pemahaman mahasiswa yang masih kurang.

Pembelajaran adalah perpaduan dua dimensi konsep yaitu belajar dan mengajar yang pelaksanaanya terlebih dahulu harus direncanakan agar bisa diaktulisasikan kemudian diarahkan pada penguasaan kompetensi maupun pencapaian indikator sebagai deskripsi hasil belajar. Pembelajaran dikatakan efektif apabila pelaksanaanya baik.Sekolah dan guru hanya memberi tugas secara beruntun sesuai rencana materi pelajaran dalam kondisi non-pandemi/kondisi biasa (Satriawan, 2020).Oleh karena itu perlu sebuah aturan yang disusun lembaga dalam hal peningkatan kualitas pembelajaran daring dari dosen yang diharapkan mampu memberikan pemahaman mahasiswa terhadap materi yang lebih optimal. Ada beberapa catatan yang harus diperhatikan agar pembelajaran daring tetap optimal yaitu berkaitan dengan kesiapan belajar diantaranya adalah kepercayaan diri terhadap penggunaan computer/internet, pembelajaran secara mandiri, pengendalian pelajar/mahasiswa, motivasi untuk belajar, dan kepercayaan diri terhadap komunikasi secara online.

Kalau Anda bisa memilih, sistem perkuliahan apa yang Anda harapkan saat pandemi Covid-19 ini ? 114 jawaban
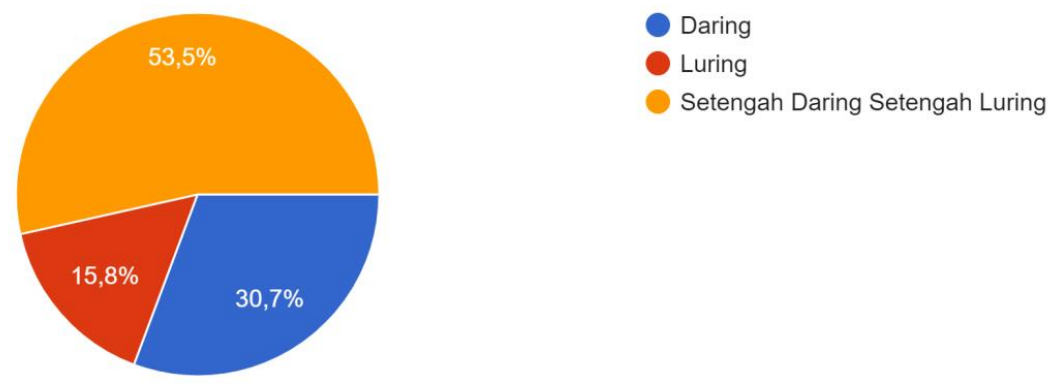

\section{Gambar 6. Sistem perkuliahan yang diharapkan mahasiswa selama Pandemi COVID 19}

Setelah melakukan pertemuan daring selama hampir 1 tahun lebih, mahasiswa diminta memberikan pendapat terhadap sistem perkuliahan yang diinginkan selama Pandemi COVID-19. Pada gambar tersebut dihasilkan bahwa mahasiswa Progam Studi Administrasi Publik menginginkan perkuliahan daring dan luring secara bergantian dengan mematuhi aturan protocol pencegahan COVID-19 sejumlah 53,05\%, mahasiswa menginginkan perkuliahan daring sejumlah 30,07\%, dan mahasiswa menginginkan perkuliahan luring sejumlah $15,08 \%$. Pada hasil tersebut terlihat bahwa mahasiswa ingin melakukan perkuliahan daring dan luring dimana perkuliahan ini dilaksankan tatap muka tetapi tidak sepenuhnya seperti halnya pertemuan khusus atau pembelajran yang diharuskan mahasiswa tatap muka langsung, Kita simpulkan bahwa mahasiswa ingin 
melakukan pembelajaran langsung (luring) karena lebih efektif disamping itu mahasiswa juga ingin pembalajaran daring karena masih takut akan penyebaran virus COVID-19.

Salah satu kendala yang Anda alami ketika perkuliahan daring yaitu?

114 jawaban

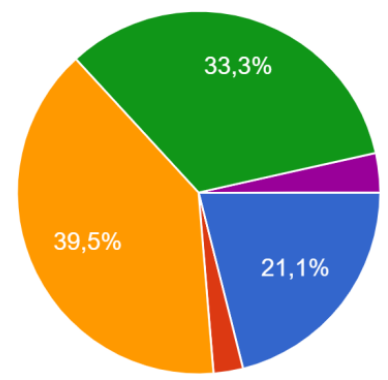

Media pembelajaran yang digunakan para dosen dominan monoton dan membuat mahasiswa merasa jenuh at... Pembelajaran dominan belum interaktif.

Pembelajarannya cenderung lebih banyak tugas.

Penyerapan materi perkuliahan sangat minimalis.

Penilaian yang dilakukan dosen berupa Penilaian Kuis, Penilaian Tengah Sem...

\section{Gambar 7. Kendala dalam perkuliahan daring di saat Pandemi COVID-19}

Terdapat beberapa kendala selama proses perkuliahan secara daring diantaranya, mahasiswa memberikan masukan bahwa media pembelajaran yang digunakan para dosen dominan monoton dan membuat mahasiswa merasa jenuh $21,01 \%$, pembelajaran dominan belum interaktif $1,87 \%$, pembelajaran secara daring ini cendrung banyak tugas $39,05 \%$, penyerapan materi perkuliahan sangat minimalis 33,03\%, dan Penilaian yang dilakukan dosen berupa penilaian kuis,UTS, kurang berintegritas 5,04\%, dapat disimpulkan bahwa kendala yang lebih dominan pada saat pelaksanaan pembelajaran terhadap mahasiswa yakni pembelajaran yang cendrung banyak tugas hal ini menjadi beban tersendiri terhadap mahasiswa yang kurang paham akan materi tetapi banyaknya tugas yang diberikan dosen.

\footnotetext{
Apakah sebelum dan selama perkuliahan daring ini berpengaruh terhadap nilai yang Anda dapatkan. Apakah mengalami penurunan, peningkatan atau tetap? 114 jawaban
}

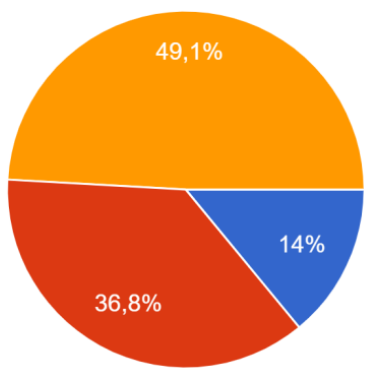

$$
\begin{aligned}
& \text { Menurun } \\
& \text { Meningkat } \\
& \text { Tetap }
\end{aligned}
$$

\section{Gambar 8. Pengaruh nilai mahasiswa pada Perkuliahan Daring}

Pada saat pandemi diberlakukannya daring tentunya dimana mahasiswa mengalami suasana yang berbeda pada saat pelaksanaan pembelajaran yang merupakan suatu hal atau kebijakan tujuan pemerintah untuk sistem pendidikan. Hal ini 
menunjukkan ke efektivitas tujuan tersebut yang merupakan ukuran keberhasilan suatu tujuan (Mardiasmo, 2017:134), yang dimana diukur berdasarkan pengaruh nilai mahasiswa terhadap kebijakan daring. Dari data diatas menunjukkan 49,01\% nilai mahasiswa mengalami tetap baik sebelum dan sesudah daring, 36,08\% mengalami peningkatan selama masa perkuliahan daring dan selanjutnya 14,91\% mengalami penurunan nilai, dapat disimpulkan bahwa nilai Mahasiswa Prodi Administrasi Publik stabil dan tetap baik pada sebelum diberlakukannya daring maupun sesudah diberlakukannya daring hal ini menunjukkan bahwa kebijakan daring cukup efektif dilihat dari segi pengaruh nilai mahasiswa yang tetap stabil dan konsisten.Pembelajaran daring memungkinkan mahasiswa memiliki keleluasaan waktu belajar sehingga dapat belajar kapanpun dan dimanapun. Mahasiswa belajar dengan santai karena bisa membuat tugas di mana saja. Selain itu, mahasiswa dapat berinteraksi dengan dosen menggunakan beberapa aplikasi seperti e-classroom, video Conference, telepon atau live chat, zoom maupun melalui whatsapp group. Beberapa penelitian telah menjelaskan bahwa ada hubungan yang signifikan antara kemandirian belajar dengan hasil belajar baik dalam pembelajaran langsung maupun dalam pembelajaran jarak jauh.

\section{Apakah Anda siap jika diterapkan kebijakan New Normal Life ? 114 Jawaban}
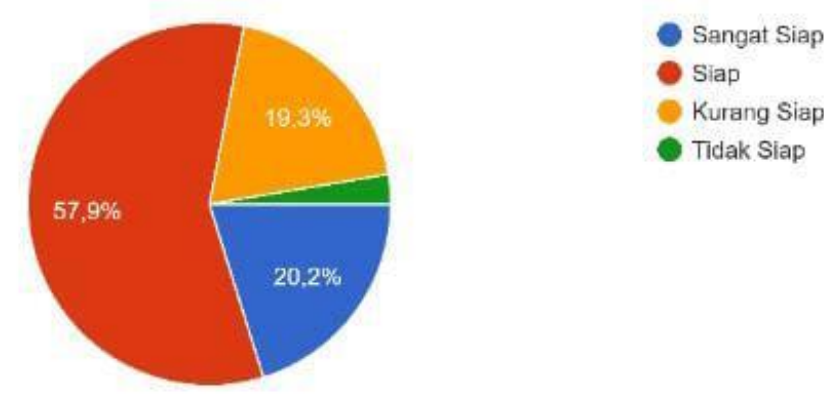

\section{Gambar 9. Kesiapan terhadap the new normal live di saat Pandemi COVID-19}

Terdapat kebijakan baru yang dibuat pemerintah seperti the new normal live (tatanan hidup baru) memberikan beberapa pandangan berbeda terhadap aktivitas perkuliahan. Tak terkecuali mahasiswa yang ingin memberikan pendapatnya seperti mahasiswa sangat siap sejumlah $20,02 \%$, sudah siap terhadap the new normal live sejumlah 57,09\%, kurang siap sejumlah 19,03\%, dan tidak siap sejumlah 3,86\%.

\section{Kesimpulan}

Berdasarkan hasil analisis, maka dapat ditarik kesimpulan bahwa, perkulihan daring pada mahasiswa Prodi Administrasi Publik UPN "Veteran" Jawa Timur Jepara diantaranya: lokasi perkuliahan daring mahasiswa secara umum dilakukan dirumah masing-masing dengan menggunakan koneksi jaringan wifi atau menggunakan paket data yang diperoleh oleh kampus/kemendikbud. Perkuliahan yang dilaksanakan di 
rumah disebut dengan stay at home untuk mematuhi protokol kesehatan yang sudah dianjurkan oleh pemerintah saat adanya pandemi Covid-19. Berdasarkan hasil analisa di dalam penelitian pada kondisi ini terlihat bahwa 56,01\% mahasiswa lebih memilih belajar dengan sistem perkuliahan daring menggunakan aplikasi zoom, sedangkan urutan ke 2 yang dipilih mahasiswa dalam perkuliahan daring adalah e-learning yaitu sejumlah 39,05\% selanjutnya untuk urutan ketiga adalah aplikasi whatsaapp sejumlah 4,94\%. Mayoritas mahasiswa lebih suka menggunakan aplikasi zoom ketika daring aplikasi zoom memiliki keunggulan yang digunakan yaitu mahasiswa bisa secara langsung tatap muka dengan dosen, mempermudah untuk diskusi serta tanya jawab,akses kapasitas ruang diberikan oleh teknologi ini cukup besar, mendukung semua platform dan dapat digunakan sebagai media bahan presentasi di dalam perkuliahan.

Pelaksanaan kuliah secara daring dengan menggunakan aplikasi zoom meskipun sudah di laksanakan dengan baik dengan menyajikan materi di dalam perkuliahan nya mahasiswa masih kesulitan dalam memahami materi nya. Pada kenyataanya perkuliahan daring sering di identikan dengan banyaknya tugas yang diberikan pada mahasiswa sehingga mengakibatkan proses perkuliahan yang kurang efektif tetapi untuk pengaruh pada nilai mahasiswa perkuliahan daring cukup efektif karena dari data diatas menunjukkan bahwa nilai mereka tetap konsisten dan stabil pada saat sebelum diberlakukannya perkuliahan daring atau sesudah perkuliahan daring.

Hasil lain menunjukkan bahwa mahasiswa siap menghadapi aturan baru the new normal live apabila dilaksanakan perkuliahan secara luring. Sedangkan untuk sistem perkuliahan yang efektif selama pandemi adalah daring dan luring secara bergantian dengan memperhatikan prinsip protocol pencegahan COVID-19.

Saran untuk peneliti selanjutnya adalah analisis 7,8,dan 9 perlu ditindaklanjuti lebih dalam terkait faktor-faktor yang dominan terhadap kurang efektifnya proses perkuliahan secara daring selama wabah Pandemi COVID-19. 


\section{Bibliography}

Alhogbi, B. G. (2017). Konsep Efektivitas. Journal of Chemical Information and Modeling, 53(9), 21-25.

Archika, N. D. (2020). Makalah Corona Virus Disease-19. https://doi.org/10.31219/osf.io/vydbg

Darmalaksana, W., Hambali, R., Masrur, A., \& Muhlas, M. (2020). Analisis pembelajaran online masa wfh pandemic covid-19 sebagai tantangan pemimpin digital abad 21. Karya Tulis Ilmiah (KTI) Masa Work From Home (WFH) Covid19 UIN Sunan Gunung Djati Bandung, 1-12.

He, W., Xu, G., \& Kruck, S. E. (2014). Online IS education for the 21 st century. Journal of Information Systems Education, 25(2), 101-106.

Hikmat, H., Hermawan, E., Aldim, A., \& Irwandi, I. (2020). Efektivitas pembelajaran daring selama masa pandemi Covid-19: Sebuah survey online. LP2M.

Huda, M., Maseleno, A., Teh, K. S. M., Don, A. G., Basiron, B., Jasmi, K. A., Mustari, M. I., Nasir, B. M., \& Ahmad, R. (2018). Understanding Modern Learning Environment (MLE) in Big Data Era. International Journal of Emerging Technologies in Learning, 13(5).

Irawan, H. (2020). Inovasi Pendidikan Sebagai Antisipasi Penyebaran COVID-19. Bengkulu: Ombudsman RI.

Kamayanthy, D. Y. (2020). Analisis Pembelajaran Menggunakan Edmodo Pada Mata Pelajaran Kewirausahaan Kelas Xii Dpib Di Smkn 1 Majalengka Tahun Ajaran 2020-2021. Journal of Chemical Information and Modeling, 1689-1699.

Kemendikbud. (2020). Data Pokok Pendidikan. Direktorat Jenderal Pendidikan Anak Usia Dini, Pendidikan Dasar dan Pendidikan Menengah.

Mardiasmo. (2017). Perpajakan Edisi Terbaru.

Maulana, H. A., \& Hamidi, M. (2020). Persepsi mahasiswa terhadap pembelajaran daring pada mata kuliah praktik di pendidikan vokasi. Equilibrium: Jurnal Pendidikan, 8(2), 224-231.

Muchtar, I. H., \& Muntafa, F. (2015). Efektivitas FKUB dalam Pemeliharaan Kerukunan Umat Beragama. Jakarta: Puslitbang Kemenag.

Rusdiana, E., \& Nugroho, A. (2020). Respon mahasiswa pada pembelajaran daring bagi mahasiswa mata kuliah pengantar hukum Indonesia UNESA. Integralistik, 31(1), $1-12$.

Sanjaya, R. (2020). 21 Refleksi Pembelajaran Daring di Masa Darurat. SCU 
Ananta Pratama, Novia Cahyaningrum, Ayu Wulandari dan Siska Zunita Anggraini

Knowledge Media.

Sugiyono, P. D. (2017). Metode Penelitian Bisnis: Pendekatan Kuantitatif, Kualitatif, Kombinasi, dan R\&D. Penerbit CV. Alfabeta: Bandung.

Widiyarta, A., \& Jayusman, T. A. I. (2017). Efektivitas Program Pos Pembinaan Terpadu (Posbindu) Penyakit Tidak Menular (PTM) di Desa Anggaswangi Kecamatan Sukodono Sidoarjo. Dinamika Governance : Jurnal Ilmu Administrasi Negara, 7(2).

Widiyono, A. (2020). Efektifitas perkuliahan daring (online) pada mahasiswa pgsd di saat pandemi covid 19. Jurnal Pendidikan, 8(2), 169-177.

A.M. Мамонтов, E. O. P. (n.d.). 済無No Title No Title. Jurnal Ilmu Administrasi Negara, 53(9), 1689-1699. 